\title{
高温・高速ガス流のもとで付着した火山灰堆積挙動と灰付着に対する損傷評価
}

\author{
石垣 誓吾*1，荒井 正行*2
}

\section{Deposition behaviour and its damage evaluation of natural volcanic ash deposited under a high temperature and a high gas flow condition}

\author{
Seigo ISHIGAKI ${ }^{* 1}$ and Masayuki ARAI ${ }^{* 2}$ \\ ${ }^{* 1,{ }^{*}}$ Department of Mechanical Engineering, Tokyo University of Science \\ 6-3-1 Niijuku, Katsushika-ku, Tokyo 125-8585, Japan
}

Received: 22 June 2016; Revised: 30 September 2016; Accepted: 1 December 2016

\begin{abstract}
Japan has a special feature that there are a lot of natural disasters compared with other country. The volcanic explosion which has occurred at the Ontake-mountain in 2012 was enormous. Recently, the volcanic explosion at Mt. Fuji has been paid attention. If Mt. Fuji is exploded, it is expected that automotive engine inhales aerosol-like volcanic ash and its ash deposits on the inner surface of cylinder, and also the breaking performance could be decreased by the volcanic ash deposited on the surface of the break disk, which will bring about a traffic confusion in the whole Kanto area. As other serious problem, the site of all landbased gas turbines utilized as power generator is mainly concentrated in Tokyo bay. If the volcanic ash falls down and is inhaled in the air intake, all generators would be stopped and a blackout would be occurred finally. It is needed that such trouble related with the volcanic explosion is prevented in advance. In this study, the volcanic ash deposit simulator, which can impact and deposit aerosol-like volcanic ash under a high-temperature and high-speed gas flow, is developed in order to identify volcanic ash deposition criterion. Here, the deposition behavior on Type 304 stainless steel plate-shaped sample is examined by changing gas pressure, gas temperature and substrate temperature condition. The ash-deposited plate is also exposed at a high-temperature in order to clarify how volcanic ash attacks the structural part.
\end{abstract}

Key words : Volcanic ash, Gas turbine, Volcanic ash deposition, 3D-deposition map, High-temperature corrosion

\section{1. 緒言}

近年，日本各地においては活火山の噴火活動が頻繁に起きており，それに伴って火山灰による被害が問題となっている. 富士山火山防災協議会により火山灰による被害は様々報告されているが, 特に自動車や航空機のジェットエンジン, 発電用 ガスタービンなどの機械構造物に及ぼす影響は甚大である（富士山ハザードマップ検討委員会, 2004）。Chen ら(Chen and Zhao, 2015)によると，航空機ジェットエンジンが活火山より大気中に噴出したエアロゾル状の火山灰を吸気した場合，燃焼 器を通過し, 溶融した火山灰がブレード表面に高速で付着して冷却孔を閉塞する恐れがあることが報告されている. これに よってエンジンの冷却性能が著しく低下し, エンジン停止に至ることは容易に想像できる. 同じブレイトンサイクルである 発電用ガスタービンにおいても同様のケースが考えられる. すなわち火山灰堆積によって発電用ガスタービンの運転停止 ならびに設備停止，最悪の場合にはブラックアウトが䀣念される.

Krämer ら（Krämer et al., 2008）は，発電用ガスタービンの動翼表面に施されているセラミック遮熱コーティング（TBC） に対する火山灰堆積こついて報告している. TBC 表面に付着した火山灰ならびに切断面を詳細観察した結果，火山灰中の 成分である $\mathrm{CaO}, \underline{\mathrm{MgO}}, \underline{\mathrm{Al}}_{2} \mathrm{O}_{3}, \mathrm{SiO}_{2}$ (以降 $\mathrm{CMAS}$ と呼ぶ) が溶融して $\mathrm{TBC}$ 内部に浸透し，これにより $\mathrm{TBC}$ の密着強度が 著しく低下寸ることを報告している. Su ら（Su et al., 2015）も，同様に火山灰を TBC 表面に塗布させて高温曝露試験を行

\footnotetext{
No.16-00281 [DOI:10.1299/transjsme.16-00281], J-STAGE Advance Publication date: 16 December, 2016

${ }^{* 1}$ 正員, 東京理科大学大学院 工学研究科（一125-8585 東京都葛飾区新宿 6-3-1）

*2 正員, 東京理科大学 工学部

E-mail of corresponding author: 4515602@ed.tus.ac.jp
} 
っており, 試験後に詳細な組織観察とXRD 解析を行っている. この結果, CMAS が TBC 内部に浸透して変質層を形成す るとともに，この変質層とセラミックス層の間での熱膨張係数差ならびにセラミック層が相変態を生じていることを明ら かにしている. そして，これらに起因して発生した内部応力により多数の内部き裂が発生したこと，このき裂発生により TBC の熱サイクル寿命が短くなったことを報告している．これらの研究成果から，火山灰堆積により室温近傍では材料表 面において毛細管結露により腐食減肉が激しく生じること，高温ではガスタービンに施されている TBCに多数の内部き裂 が発生することが明らかにされた. これらの研究では, 溶融した火山灰が機械部品に及ぼす影響について詳細に研究が行わ れているものの，いずれの試験においても火山灰を混合したエタノールを塗布した試験片を対象に高温暴露試験が行われ ており, 火山灰の堆積プロセスが無視されている. 実際の発電用ガスタービンにおいては, 圧縮器ならびに燃焼器により高 温高速の作動ガスによって溶融した火山灰が動・静翼表面に衝突するなどダイナミックなプロセスを経て火山灰が機械構 造物表面に堆積し，供用中に損傷が発生するのが一般的である.

以上の背景に鑑みて本研究では, 高温高速のガス流下で火山灰が機械構造物に堆積することを想定し，この状態を模擬し うる火山灰堆積シミュレータを開発する. 開発したシミュレータにおいては, コンプレッサーから導入された空気を電気炉 で加熱することで昇圧するとともに，ラバルノズルを介してこの空気を高速で試験片表面に吹き付ける. その際, ラバル， ズルにおける絞り部から火山灰を高速空気流に送り込むことでエアロゾル状火山灰を再現する. 本研究では, 火山灰として 霧島山新然岳から採取した粉末を用いた. また, 試験片にはオーステナイト系ステンレス鋼SUS304 鋼平板を準備し, コン プレッサー圧力, 電気炉温度条件, 平板試験片と噴出ノズルの距離, 基材温度が火山灰堆積量に及ぼす影響について調査す る.さらに, 噴射試験により火山灰堆積した試験片と火山灰とエタノールの混合溶液を塗布したこれまでの方法による試験 片を対象に高温曝露試験を行い，本研究で注目したダイナミックな付着プロセスが表面損傷形態に及ぼす影響について明 らかにする。

\section{2. 火山灰堆積シミュレータの概要}

図 1 に本研究で試作した火山灰堆積シミュレータの系統図を示す. 本シミュレータは, ガス導入部 (図中(a)), ガス加熱部（図中(b)）, 火山灰導入部および火山灰噴射部（図中(c)）, 試験片固定部（図中(d)）から構成される. 本研究では，作動ガスとして空気（以下，単に”ガス”と称する）を利用し，これをコンプレッサー（エアコン プレッサー型式 GP5-4S，（株）東芝製）により配管内部に導入する．配管内部に導入されたガスを電気炉（セラ ミック電気管状炉型式 ARF-30M，（株）アサヒ理科製作所製）で加熱し，これを高温高圧状態にする. 最後にこ の高温高圧ガスを噴射ノズルによりエアロゾル状火山灰にし，これを試験片固定部に取り付けた平板基材（寸法 100×100×1mm）に吹き付ける. 図 2 に火山灰堆積シミュレータの外観写真を示す.

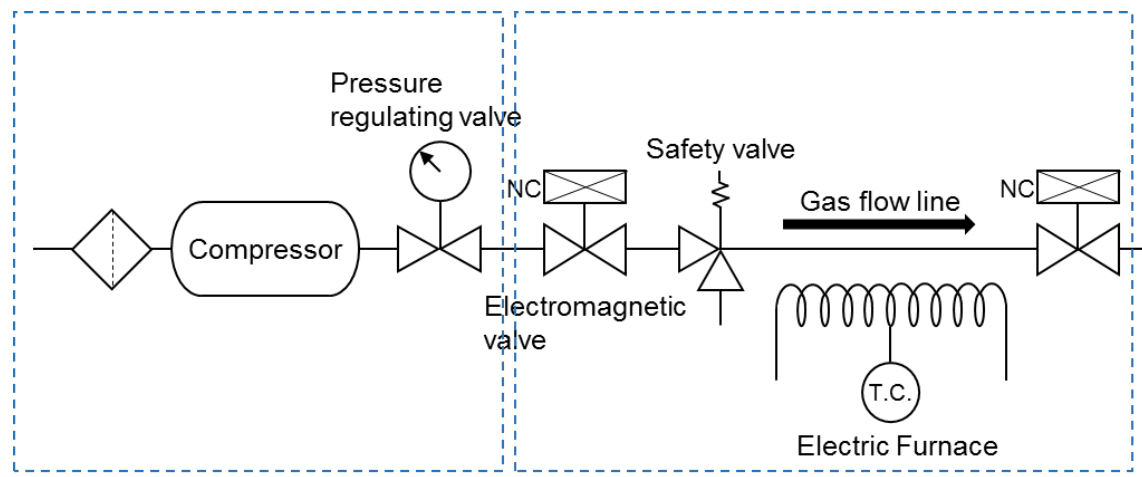

(a) (b)

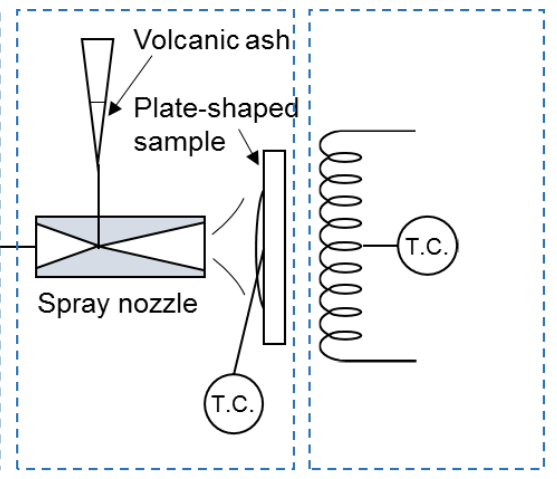

(c)

Fig. 1 Schematic diagram of volcanic ash deposition simulator. 


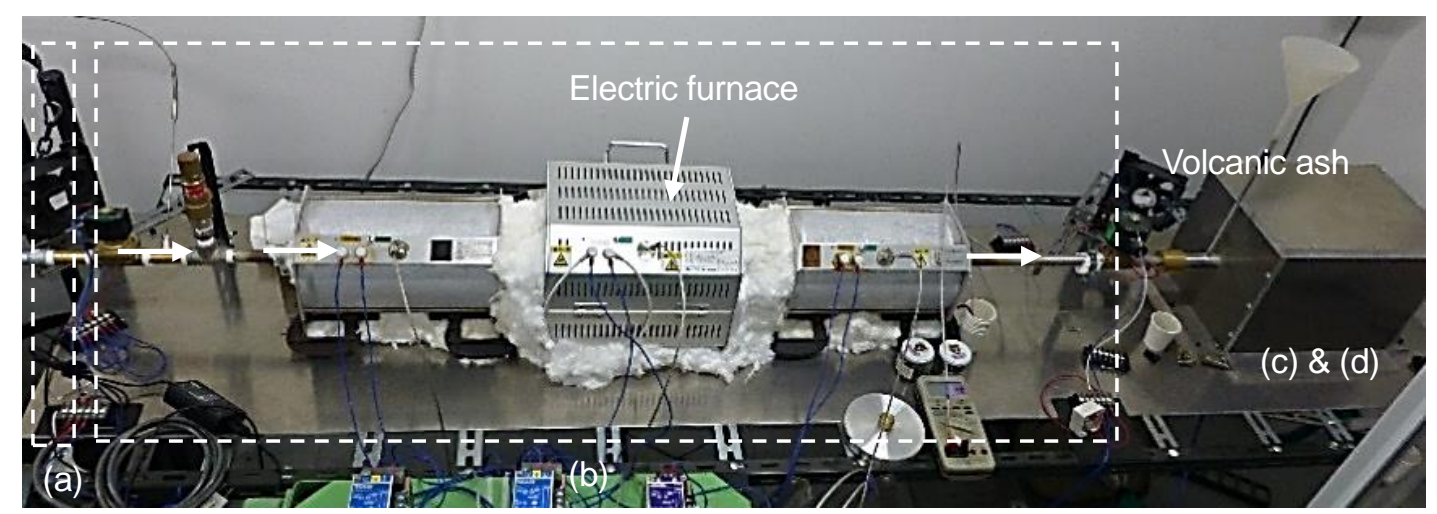

(a)Main equipment.

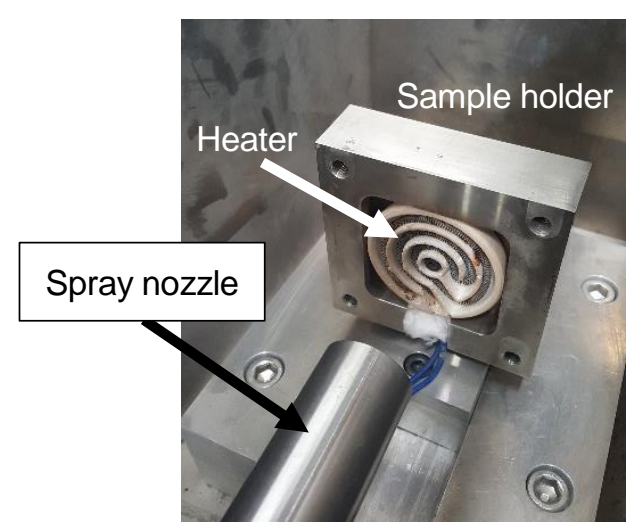

(b)Sample holder and heater.

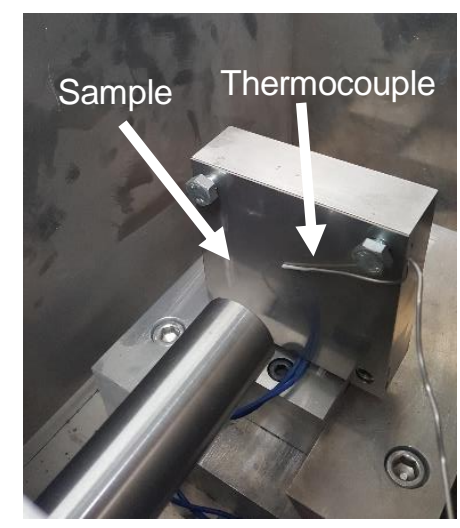

(c)Plate-shaped sample and thermocouple.

Fig.2 Picture of volcanic ash deposition simulator developed in this study.

本研究で採用した噴射ノズルの内部形状はラバルノズルであり，ガス流速を音速域近傍まで達することを可能 とする. 本研究では，ラバルノズルの絞り形状をNACAにより規定されているノズル内での超音速流についてま とめた技術資料に基づいて計算した(Crown, 1948). これにより決定されたノズル形状を図 3 に示す。管径 $\phi 16$ の ノズル入口部から導入された高温高圧ガスを管径 $\phi 6$ まで絞るように設計されている．また，絞り部の上部には 火山灰を投入するための細孔が設けられており，ここから火山灰をノズル内部に投入した後に高速ガスを流すこ とで，エアロゾル状火山灰が高速流で試験片表面に吹き付けられるよう工夫してある。なお，ノズル材には加工 が容易な SUS420を用いた。

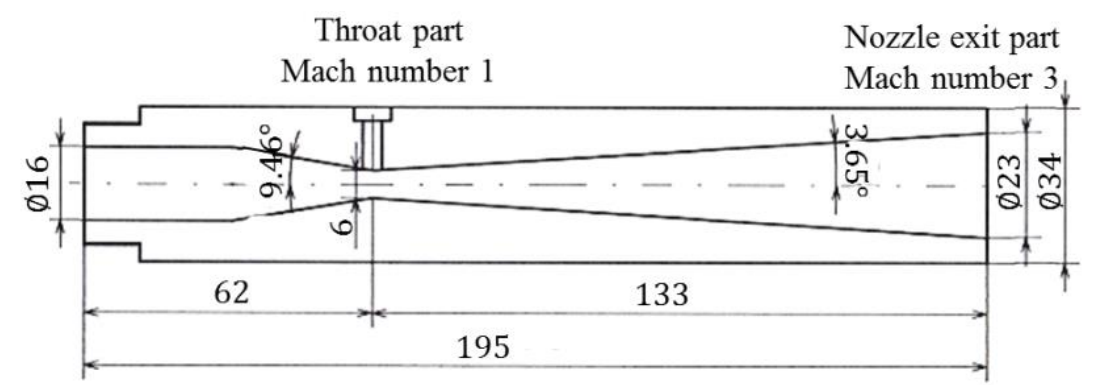

Fig.3 Cross section of nozzle determined based upon NACA design sheet. 


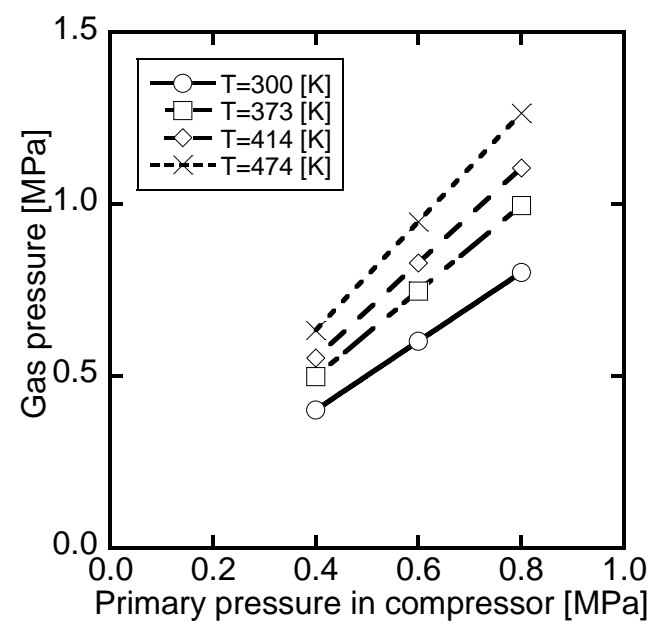

Fig.4 Relationship between primary pressure in compressor and gas pressure.

本シミュレータでは, ガス導入部に取り付けた圧力計によりコンプレッサー圧力を測定した (図 1). ところで, ガス加熱部においては，配管が電気炉で加熱されるためにコンプレッサー圧力よりもさらにガス圧力が昇圧する ことになる．このため，配管内部のガス圧力を算出するためにつぎの気体の状態方程式

$$
P=\rho R T
$$

により配管内ガス温度 $\mathrm{T}$ と関係付けた。 ここで, $\rho$ は気体密度, $R$ は気体定数, $T$ は配管内ガス温度である. なお, 配管内ガス温度 $T$ は配管に挿入した熱電対により測定した。一方, 空気の平均分子量は $28.96[\mathrm{~g} / \mathrm{mol}]$ であると から，室温 300[K]，圧力 $1[\mathrm{~atm}]$ における空気密度 $\rho_{\text {air_room }}$ は，

$$
\rho_{\text {air_room }}=28.96 \div 22.4 \times \frac{273}{300}=1.177\left[\mathrm{~kg} / \mathrm{m}^{3}\right]
$$

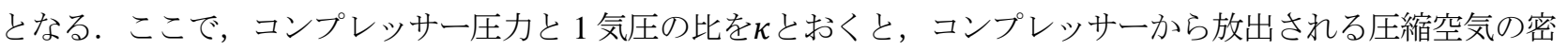
度 $\rho_{\text {air_compressor }}$ は, $1.177 \kappa$ となり, これと式(1)よりガス圧力 $P[\mathrm{~Pa}]$ は,

$$
P=1.177 \kappa \times 287 \times T
$$

となる. 図 4 に電気炉により加熱された配管内ガス温度ごとのコンプレッサー圧力とガス圧力の関係を示す．い ずれの配管内ガス温度条件下においてもコンプレッサー圧力に比例してガス圧力も増加する. さらに配管内ガス 温度条件に伴ってガス圧力も増加することがわかる.

つぎに以上により算出したガス圧力 $P$ 基づいてノズル出口から噴射されるガス流速を評価する．まず，本研 究で設計したラバルノズルにおいて超音速流れとなるための必要圧力を文献に基づいて試算した。この結果，お よそ 11 気圧と見積もられた(片野田，2010). 本試験において設定したガス圧力は同圧力よりも低かったことか らノズル管内は非圧縮性流れとみなせることがわかった。この仮定のもとでノズル内部に対してベルヌーイの定 理が適用でき，これによるノズル出口でのガス流速りは，

$$
v=\sqrt{2 g \Delta h}
$$

で表される.ここで， $\Delta h$ は圧力差であり

$$
\Delta h=\left(P-P_{0}\right) / \rho g
$$


である.ここで， $P$ は配管内ガス圧力， $P_{0}$ は大気圧， $\rho$ は気体密度である. 図 5 にガス圧力とノズル出口でのガス 流速の関係を示寸．図よりガス温度によらずガス圧力とガス流速との間には相関関係があることがわかる．以降 では，この関係に基づいてガス圧力条件をノズル出口部でのガス流速に変換することとした.

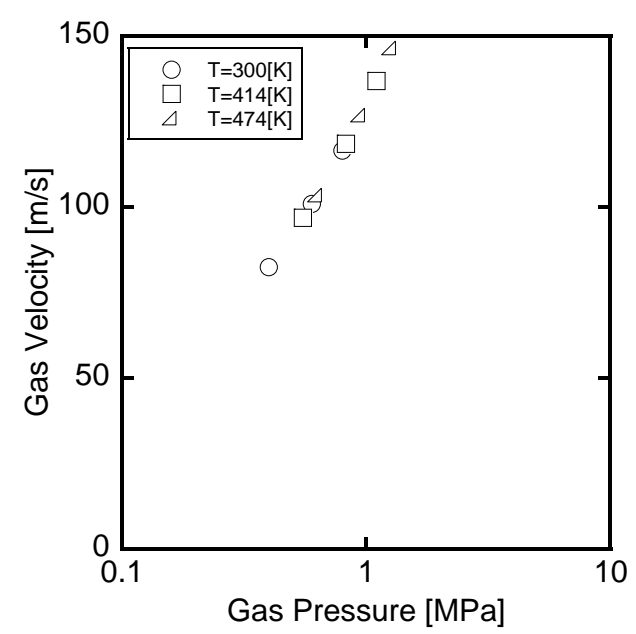

Fig.5 Relationship between gas pressure and gas velocity at the nozzle outlet.

\section{3. 火山灰噴射試験}

はじめに，本研究で試作したシミュレータの基本的な特性を把握するために火山灰の噴射量を調べることとし た．ここでは，電気炉によりガスを加熱せず，ガス圧力条件のみを変化させたときにノズルより噴射された火山 灰の噴出量を計測した．なお，以降ではそれぞれのガス圧力条件に対して式(4)で評価されたガス流速を示すこと にする. 試験条件を表 1 に示寸.

本試験で用いた火山灰は, 2011 年 1 月 26 日および 27 日に宮崎県と鹿児島県の県境に位置する霧島山火山群の 一峰の新然岳から噴出し, 宮崎県高原町青年団が皇子原公園で採取したものである. 採取した火山灰の SEM 写 真を図 6 に示す.

図 7 にガス流速を変化させた時の火山灰噴出量を示す. 図中の $\mathrm{t}$ は噴射時間を示す. 図より, 噴射時間 $\mathrm{t}=1$ 秒 の結果に注目すると, ガス流速に伴い火山灰噴出量も単調に増加し, ガス流速がおよそ $100 \mathrm{~m} / \mathrm{s}$ になると噴出量が 最大となり, それ以降はガス流速が増加しても噴出量は低下するようになる. これは, 管内摩擦損失に起因して 噴出量が低下したためと考えられる．また，噴射時間 $\mathrm{t}$ が長くなると，火山灰の噴出量も増加する．ただし，噴 出量が最大となるガス流速はおよそ $100 \mathrm{~m} / \mathrm{s}$ と一定であった.

Table1 Preliminary test of volcanic ash deposition.

\begin{tabular}{|c|c|}
\hline Gas temperature[K] & 300 \\
\hline Gas pressure[MPa] & $0.1 \sim 0.9$ \\
( Gas velocity[m/s] ) & $(41 \sim 124)$ \\
\hline Injection period[s] & $1,2,3$ \\
\hline
\end{tabular}




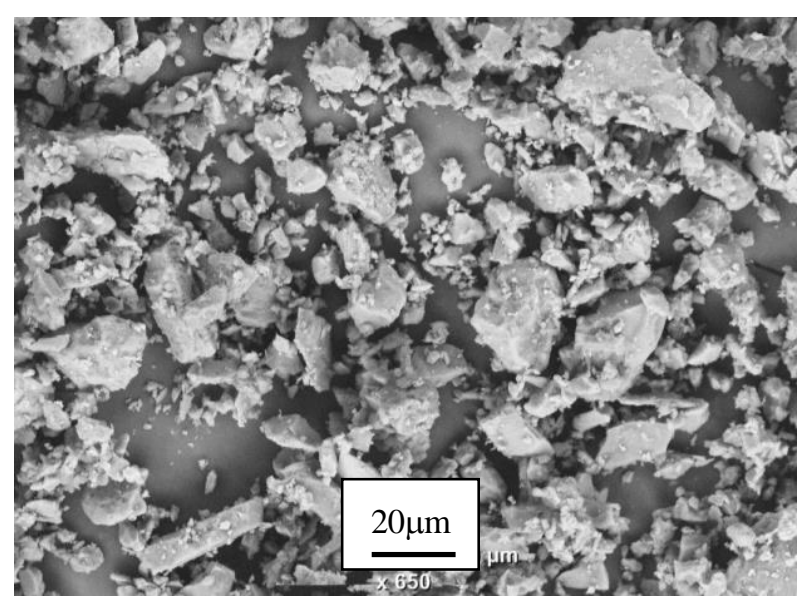

Fig.6 SEM observation of volcanic ash.

つぎに先の試験結果を踏まえて，ガス流速が $100 \mathrm{~m} / \mathrm{s}$ となるガス圧力のもと噴射時間 2 秒に固定して噴射ノズ ルと試験片の距離（以下，噴射距離と呼ぶ）と火山灰の堆積量の関係について調べた. 試験条件を表 2 に示す. 本研究では, 試験片表面に堆積した火山灰堆積量をつぎの手順に従って評価した. 火山灰が堆積した試験片表面 を光学顕微鏡にて観察, 撮影寸る. 図 8(a)に火山灰を噴射堆積させる前の, (b)に噴射距離 $6 \mathrm{~mm}$ で噴射堆積後の 試験片表面の光学顕微鏡写真を示す．試験前の試験片表面は研磨処理をしているため一様であるのに対して，噴 射試験後の試験片表面は火山灰の噴射によって試験片表面に凹凸が生じ，数マイクロ〜数十マイクロの粒径の火 山灰が堆積していることがわかる. その後, 画像処理ソフトウェア「ピクトベアー」を用いて撮影画像を白と黒 に二值化した. 図 9 に図 8 の写真の二值化画像を示寸. 図 9(a)を見ると, 二值化処理によって研磨した試験片表 面は一様に白で表されている，そして図 9(b)を見ると，試験後の試験片表面は堆積した火山灰が黒で示されてい ることがわかる，その後，デジタル画像ソフト「マイクロアナライザー」により二值化画像の白と黒の割合（以 下, 火山灰堆積率と呼ぶ）を評価し, みかけの火山灰の堆積量とした. 図 9 において火山灰堆積率を計測すると,

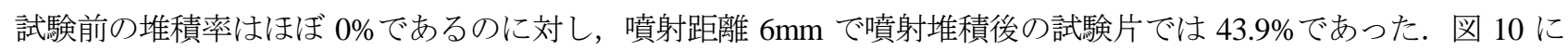
噴射距離に伴う火山灰堆積率の変化を示す. 図より, 火山灰堆積率は噴射距離 $2 \mathrm{~mm}$ で最大であり, この距離から 離れるにつれて火山灰堆積率は低下していくことがわかる.

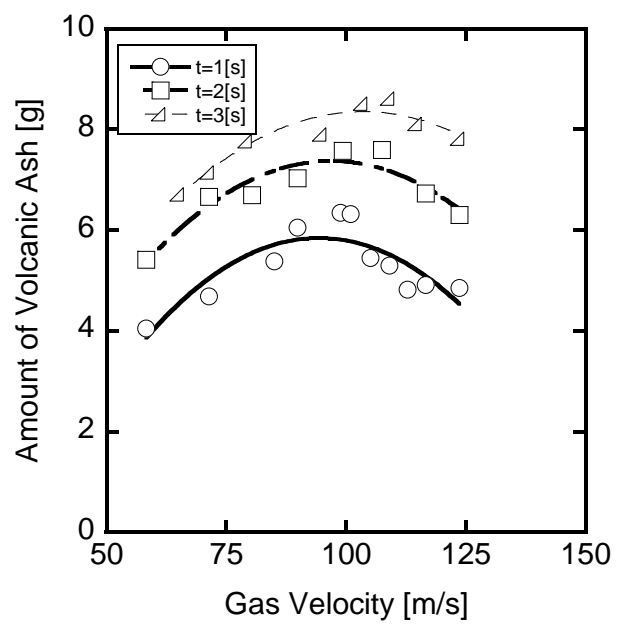

Fig.7 Relationship between gas velocity and the amount of injected volcanic ash. 
Table2 Test condition of injection test.

\begin{tabular}{|c|c|}
\hline Gas temperature[K] & 300 \\
\hline Gas pressure[MPa] & 0.6 \\
( Gas velocity[m/s] ) & $(98)$ \\
\hline Injection period[s] & 2 \\
\hline Injection distance[mm] & $2,4,5,6,10$ \\
\hline
\end{tabular}

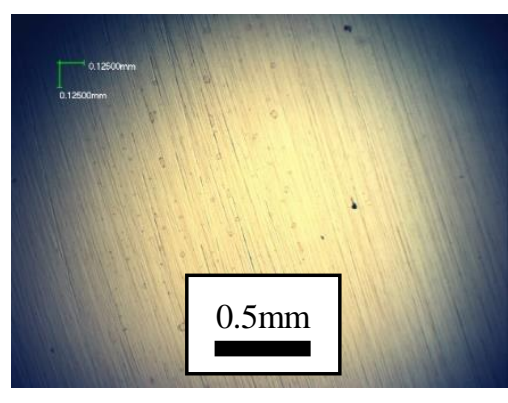

(a)Before injection test.

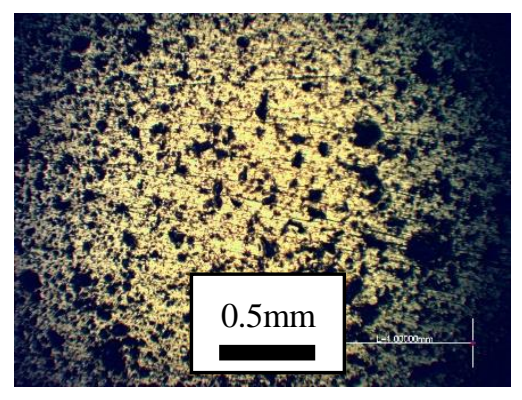

(b)After injection test.

Fig.8 Images by optical microscope.

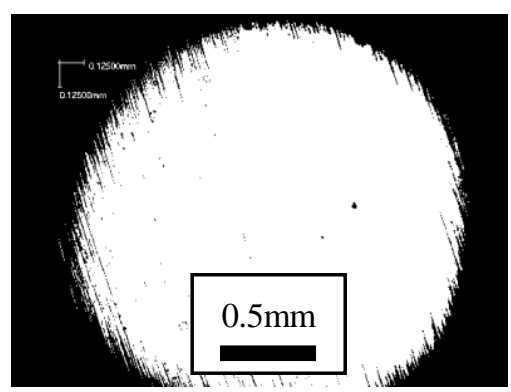

(a)Before injection test.

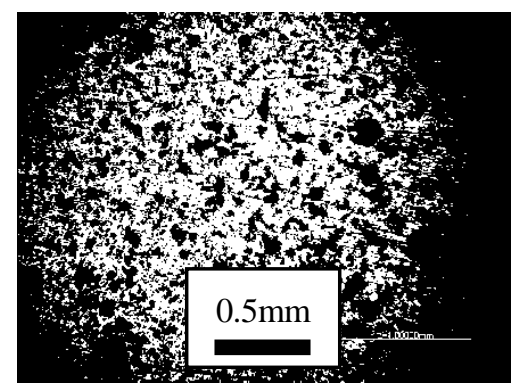

(b)After injection test.

Fig.9 Images by binarization processing.

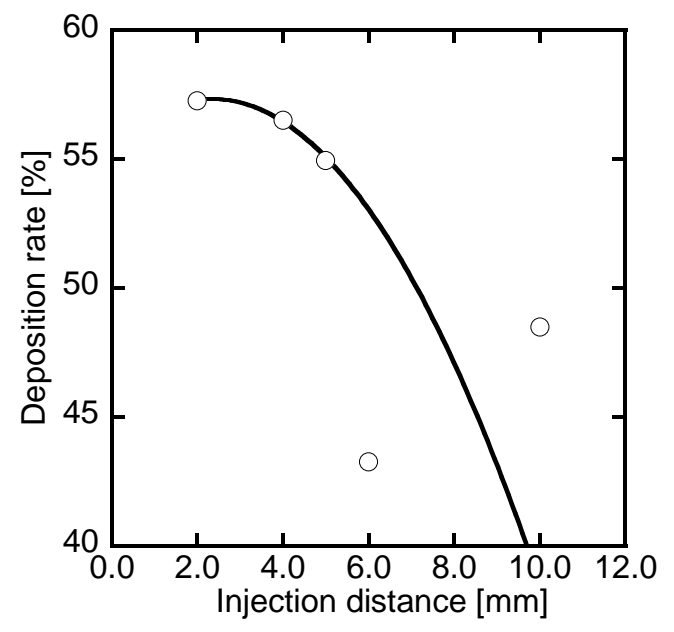

Fig.10 Relationship between injection distance and deposition rate.

以上の試験結果に基づき，噴射距離 $2 \mathrm{~mm}$ ，噴射時間 2 秒に固定するとともに，試験片加熱温度（以下，基材温 度と呼ぶ)，電気炉加熱によるノズル出口部でのガス温度，ガス圧力（ガス流速）を試験条件とし，様々な試験条 件の組み合わせのもとで火山灰堆積試験を実施した。ここで，ノズル内は等エンタルピー過程とみなせばノズル 
出口より噴射されるガス温度は配管内で加熱されたガス温度と等しいと考えられる. また，同一の環境下で全て の試験を行うことにより湿度などの火山灰堆積に影響を及ぼすと考えられる諸因子を排除できるように工夫した. 試験片加熱には，図2(b)および(c)に示すように試験片固定部内部にニクロム線ヒーターを設置し，試験片表面に 接触させた $\mathrm{K}$ タイプシース熱電対により計測された温度が基材温度条件に一致するよう PID 制御した. 試験条件 を表 3 に示寸. 試験条件は大きくつぎの 2 種類に分けられる. i)試験条件 I:火山灰堆積の主因子を明らかにするた めにコンプレッサー圧力を 0.4 0.8MPa と比較的高圧側に設定した条件. ii)試験条件 II: 火山灰が堆積しにくい臨 界条件を明らかにするためにコンプレッサー圧力を比較的低圧に設定した条件.

Table3 Test condition of deposition test I and II.

\begin{tabular}{|c|c|c|}
\hline & Deposition test I & Deposition test II \\
\hline $\begin{array}{c}\text { Electric furnace temperature[K] } \\
\text { ( Gas temperature[K] })\end{array}$ & $\begin{array}{c}300,973,1273 \\
(300,414,474)\end{array}$ & $\begin{array}{c}300,573,773 \\
(300,353,400)\end{array}$ \\
\hline Primary pressure in compressor[MPa] & $0.4,0.6,0.8$ & $0.05 \sim 0.35$ \\
( Gas velocity[m/s] ) & $(82,101,117)$ & $(32 \sim 77)$ \\
\hline Substrate temperature[K] & $300,373,473,573$ & 373,573 \\
\hline
\end{tabular}

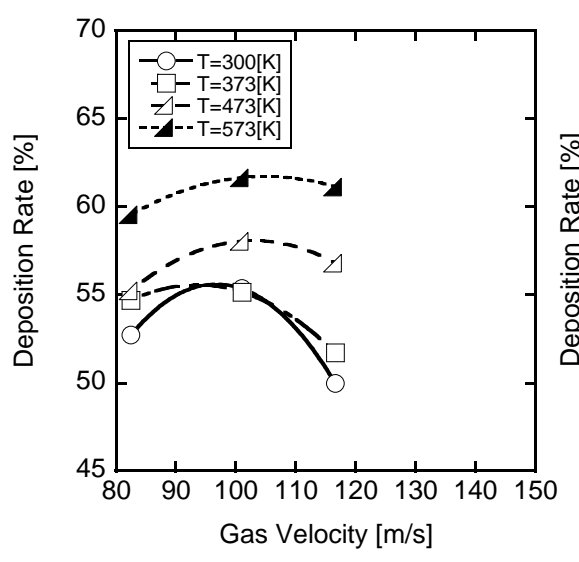

(a)Gas temperature $300 \mathrm{~K}$.

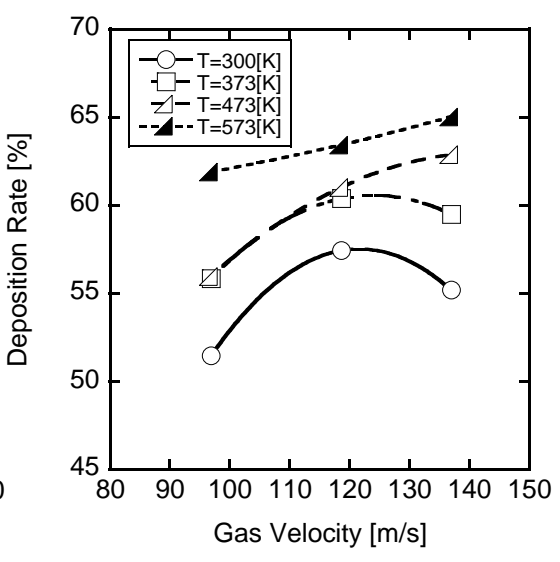

(b)Gas temperature $414 \mathrm{~K}$.

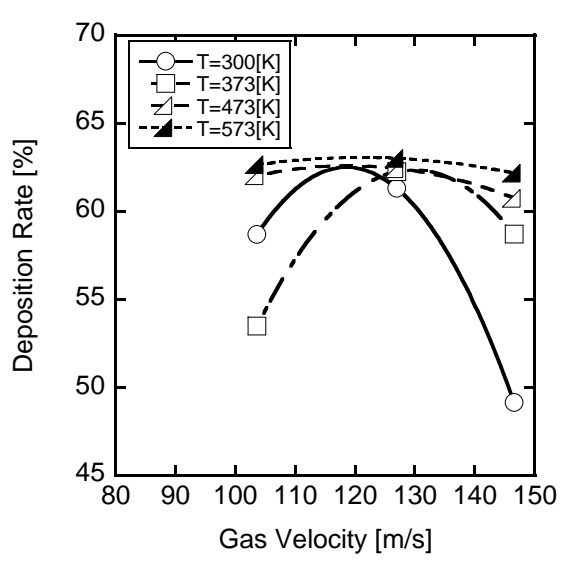

(c) Gas temperature $474 \mathrm{~K}$.

Fig.11 Relationship between gas velocity and deposition rate in deposition test I.

図 11 に試験条件 I におけるガス流速と火山灰堆積率の関係を示す. 図 11(a)はガス温度が室温 (300K), 図 11(b) は414K，図 11(c)は474K をそれぞれ示している，なお，図中の T は基材温度条件を示す．はじめに図 11(a)に注 目すると, 基材温度条件によらずガス流速の上昇に伴って火山灰堆積率も増加し, ガス流速がおよそ $100 \mathrm{~m} / \mathrm{s}$ にな ると火山灰堆積率は最大となる. その後, ガス流速を増加させても火山灰堆積率は減少していくことがわかる. 図 11(b)および(c)においてもガス流速と火山灰堆積率の間には同様の傾向が見られ，ガス流速 120 130 $/ \mathrm{s}$ におい て火山灰堆積率は最大となっている。つぎに基材温度の影響について注目すると, いずれのガス温度条件におい ても，基材温度の上昇に伴い火山灰堆積率も増加することがわかる．これは，基材温度を高くすることで火山灰 が噴射衝突した際に容易に基材が塑性変形し堆積しやすくなるためと考えられる．一方，ガス温度条件の影響に ついては, 同一の基材温度条件のもとで比較すると, ガス温度に伴って火山灰堆積率は概ね増加しているようで ある.これは，ガス温度の上昇によって火山灰粒子の温度が上昇したためと考えられる. 


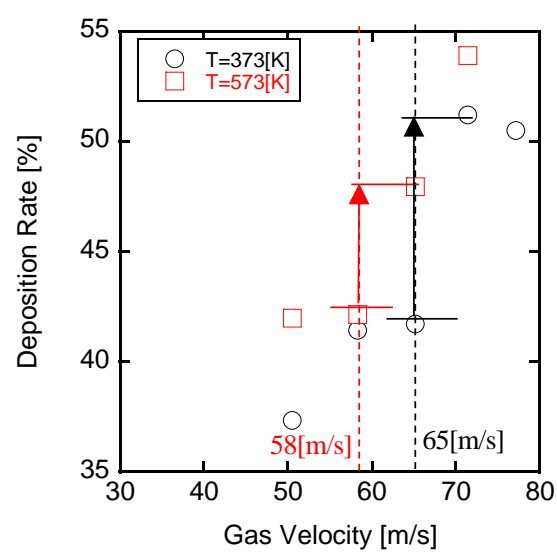

(a)Gas temperature $300 \mathrm{~K}$.

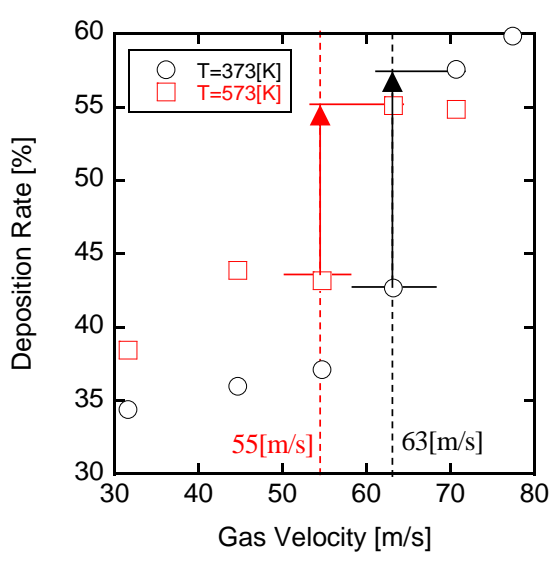

(b)Gas temperature 353K.

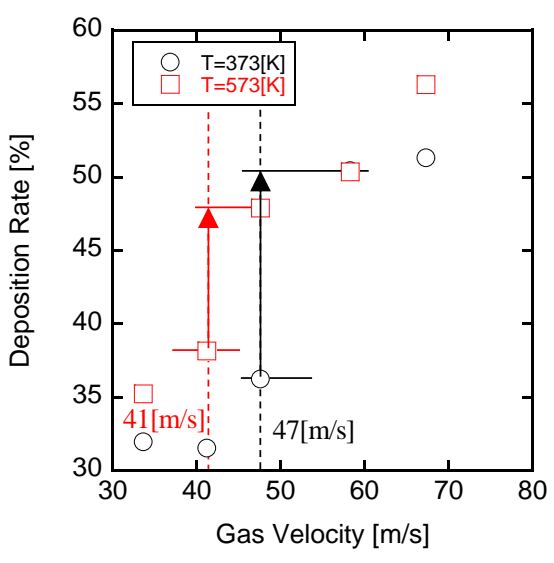

(c)Gas temperature $400 \mathrm{~K}$.

Fig.12 Relationship between gas velocity and deposition rate in deposition test II.

図 12 に試験条件 II のときの試験結果を示寸．はじめにガス温度 $353 \mathrm{~K}$ ，基材温度 $373 \mathrm{~K}$ の結果に注目すると， ガス流速が $63 \mathrm{~m} / \mathrm{s}$ よりも遅い速度で噴射させた場合, 堆積率は 30 40\%であるのに対し, 流速が $63 \mathrm{~m} / \mathrm{s}$ を超える と急激に堆積率が増加していることがわかる．他の試験条件においても，ガス流速が遅い場合堆積率は 30 40\% ほどであるのに対し，あるガス流速以上では急激に堆積率が増加している．このことから急激に火山灰堆積率が 増加する臨界速度が存在することがわかる．図中において臨界速度を矢印で示す，ガス温度 $300 \mathrm{~K}$ のときに基材 温度が $373 \mathrm{~K} ， 573 \mathrm{~K}$ における臨界速度はそれぞれおよそ $65[\mathrm{~m} / \mathrm{s}], 58[\mathrm{~m} / \mathrm{s}]$ であることから, 基材温度の上昇ととも に臨界速度が低下寸ることがわかる．また，ガス温度が 353K と 400K で基材温度 $373 \mathrm{~K}$ の結果を比較すると臨界 速度はそれぞれおよそ $63[\mathrm{~m} / \mathrm{s}], 47[\mathrm{~m} / \mathrm{s}]$ であることから, 基材温度同様, ガス温度の上昇とともに臨界速度が低下 している. これは試験条件 I の結果同様に, 基材温度, ガス温度を高くすることで基材が塑性変形し火山灰が堆 積しや寸くなるため, 臨界速度が低下したものと考えられる. これらのことから, 火山灰が堆積しにくい臨界速 度が存在することがわかった。

以上より火山灰堆積の試験結果に基づき火山灰堆積マップを作成した. 図 13 に試験条件 II に基づいて作成し た臨界条件を表す 3 次元マップを示す．図に示寸等高面内のガス流速，ガス温度ならびに基材温度条件であれば 火山灰が機械構造物にあまり堆積することなく設備を安全に運用できることを意味している.

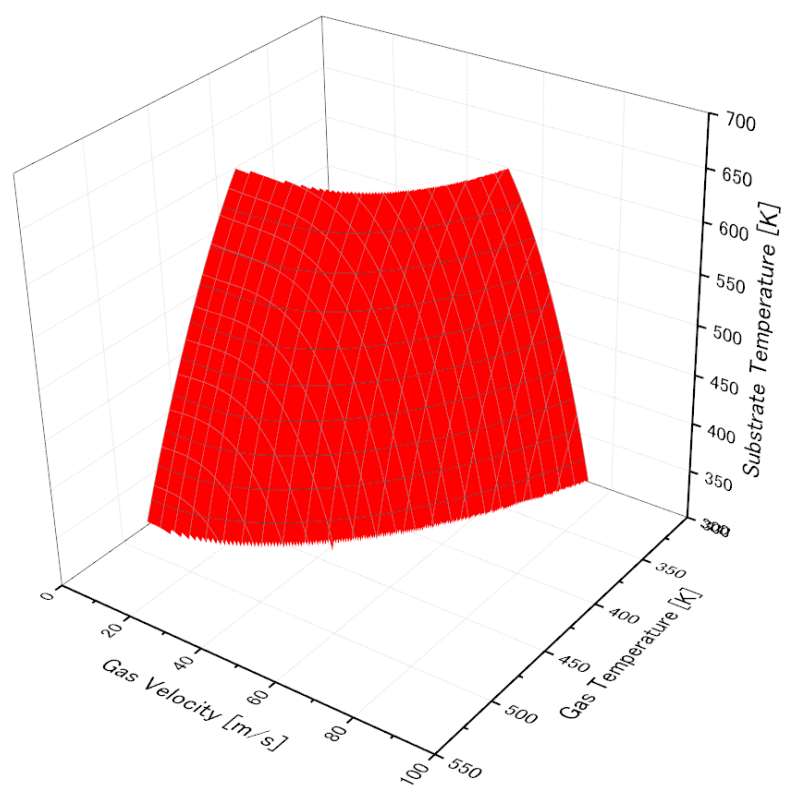

Fig.13 3D-Critical map for preventing from ash deposition. 


\section{4. 高温曝露試験と腐食評価}

機械構造物部品表面に火山灰が付着しているメカニズム，および高温環境下で堆積した火山灰による基材に引き 起こしうる二次的損傷を調べることを目的に，第 3 章で実施した噴射試験後の火山灰堆積試験片に対して高温曝 露試験するとともに走査型電子顕微鏡（SEM）による組織観察を行った.

図 14(a)に噴射試験前，図(b)に噴射試験後の切断面を観察面とし埋め込み樹脂を用いて SEM 観察した結果を示 す．なお，噴射条件は，ガス温度 474K，ガス流速 $127[\mathrm{~m} / \mathrm{s}] ，$ 基材温度 $473 \mathrm{~K}$ に相当している．また，観察面はバ フまで研磨したのち，結晶組織を明確にするため王水でエッチング処理を施している．図 14(a)において滑らかな 表面形状であった試験片が，図 14(b)を見ると火山灰が衝突することにより基材表面が大きく変形していること がわかる．噴射試験後の切断縦断面を見ると，図 14(b)のような火山灰による基材の変形箇所が無数に確認され た.このことから，火山灰粉末が基材表面に対して高速衝突し，力学的結合のもとで火山灰が基材に付着してい ることが類推される.

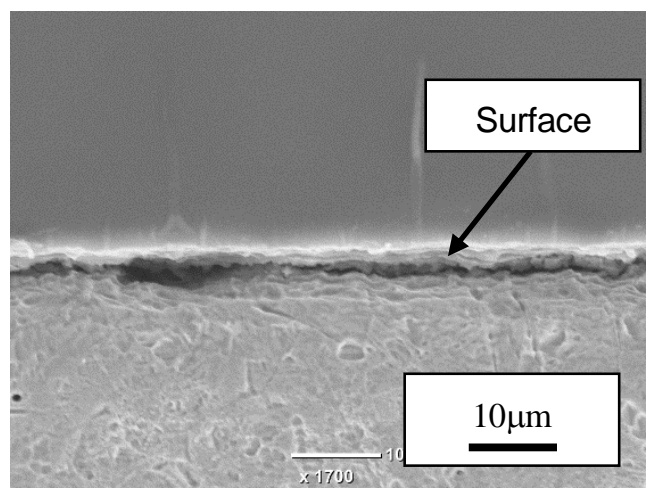

(a)Before impact test.

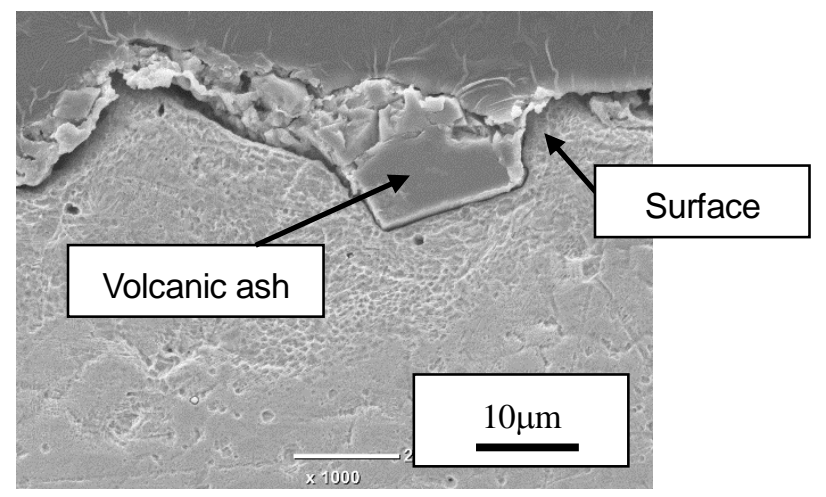

(b) Volcanic ash impact.

Fig.14 SEM observation of ash impacted sample.

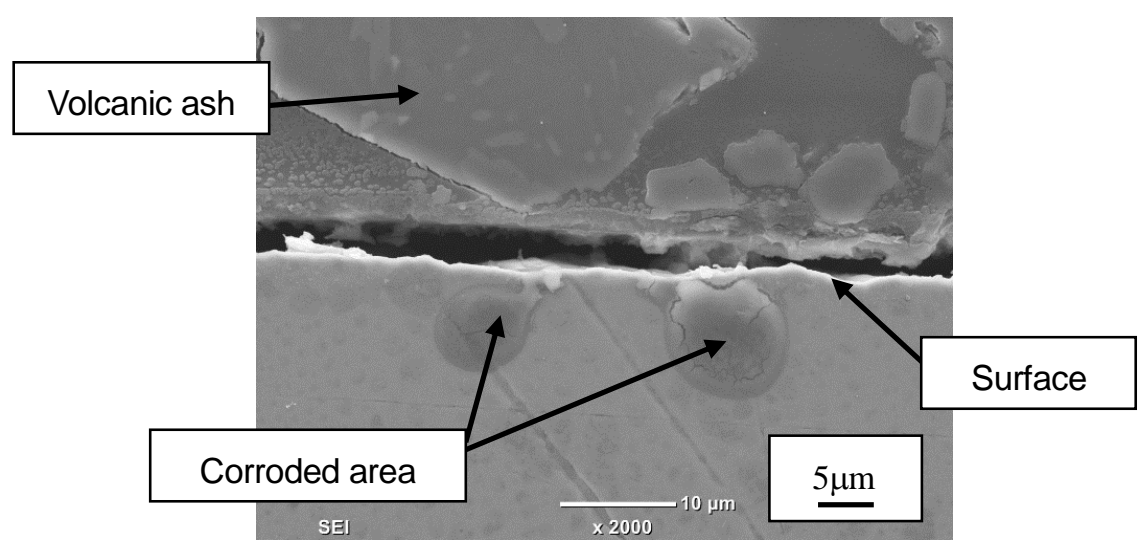

Fig.15 SEM observation of high-temperature exposed specimen which was painted by a mixture of ethanol and volcanic ash.

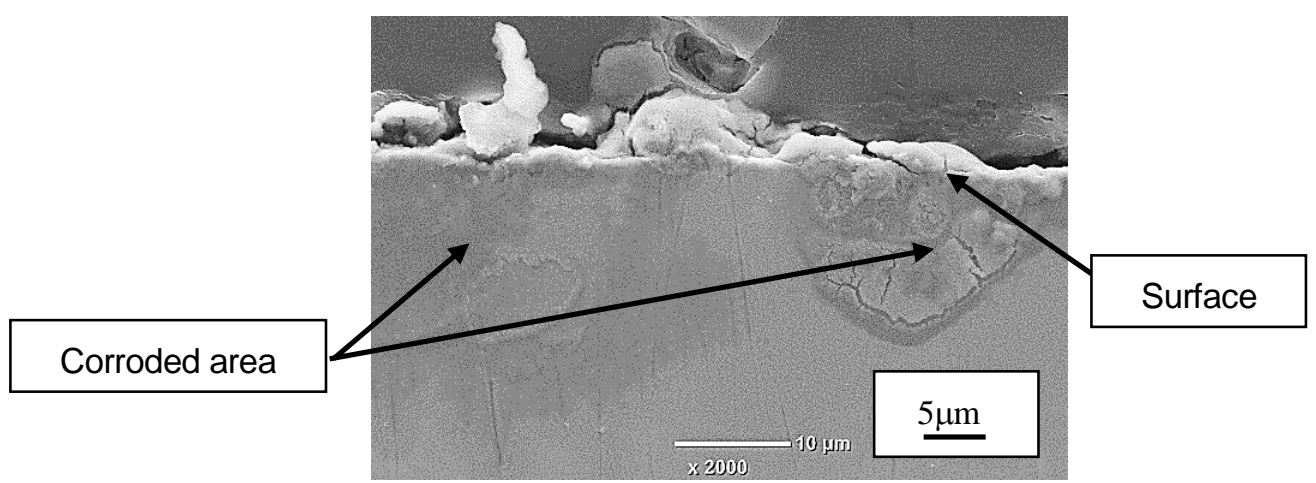

Fig.16 SEM observation of high-temperature exposed specimen which was impacted by volcanic ash. 
はじめに火山灰とエタノールの混合溶液を塗布した試験片に対して $873 \mathrm{~K}, 120$ 時間にて高温曝露試験した試験 片縦断面観察結果を図 15 に示寸，基材表面付近において局所的に薄い灰色の層が生成されていることがわかる. この層の化学成分を調べるために EDS 分析を行った. その結果, 変色層では高温酸化による $\mathrm{O}$ ともとの基材に は含まれていない $\mathrm{Cl}$ が検出された。これより，火山灰中に含まれる $\mathrm{Cl}$ の成分が基材表面にできている不働態酸 化膜を破壊し，局部的な腐食が生じたものと考えられた.

つぎに火山灰噴射試験により火山灰が堆積した試験片に対して先ほどと同じ条件下で高温曝露試験した. 図 16 に高温暴露試験後の切断面観察結果を示寸. アセトンと火山灰を混合した溶液を塗布したときの結果と同様に, 火山灰噴射試験による火山灰堆積試験片でも試験片表面近傍で腐食している様子が確認された。 なお，先に示し た火山灰とエタノールの混合溶液を塗布した試験片において認められたのと同様に図中の灰色の変色層において $\mathrm{Cl}$ 成分が検出された. ただし, 火山灰噴射試験による堆積試験片の方が表面からの腐食深さはやや深く, 表面で 広がっているように見受けられた。

そこで, 試験片に塗布する火山灰の量を一定にし, 曝露温度条件 $873 \mathrm{~K}$ 一定のもとで $25,60,120,250,500$ 時 間と曝露時間を変化させたときの最大腐食深さを調べた結果を図 17 に示す. 図より，いずれの試験片において多 少のばらつきはあるものの曝露時間に伴い腐食深さは概ね増加している. 周知のように腐食反応が進んでいる初 期段階では, 試験時間 $t$ と腐食深さ $\delta$ の間には一般的に放物線則 $\delta=\sqrt{k t}$ が成立することが知られている. 図中に最 小二乗法により放物線則による回帰曲線が示されているが，このことから火山灰堆積による腐食進行現象におい ても放物線則が成立していることがわかった．さらに，エタノールと火山灰の混合溶液を塗布した試験片に比べ て火山灰を衝突させることで堆積した試験片の方が腐食深さは深いようである. 詳しいメカニズムについては不 明であるが，火山灰が衝突することで基材表面が塑性変形し，これにより衝突点近傍にすべり帯が形成される. このすべり帯に沿って火山灰中の化学成分が基材深く浸透することで高温腐食が進行したものと考えられる.

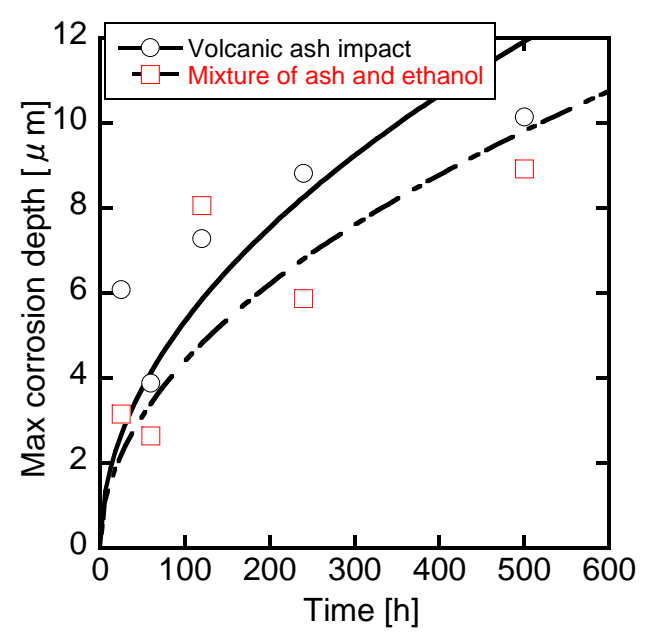

Fig.17 Relationship between exposure time and corrosion depth.

\section{5. 結 言}

本研究では, 高温高速のガス流下で火山灰が機械構造物に堆積寸ることを想定し, この状態を模擬しうる火山灰堆積シミ ユレータを開発した. そして本シミュレータにおけるガス流速, ガス温度といった噴射条件が火山灰の堆積率に及ぼす影響 を調べ，火山灰の堆積挙動を明らかにした. その結果，以下のことが明らかとなった.

本シミュレータにおいては, 噴射距離 $2 \mathrm{~mm}$ のもとガス流速を 120 130[m/s]のときに火山灰の堆積率は最大となること, また, ガス温度, 基材温度条件に伴って火山灰の堆積率も増加することがわかった. 一方, ガス流速条件を高くしていくと, 火山灰が急激に堆積する臨界条件が存在することもわかった. 以上の試験結果に基づき, 火山灰堆積マップを作成した. こ れにより，火山灰が堆積することなく機械設備を安全に運用するためのクライテリオンを提案した. 
高速ガス流下で火山灰が機械構造物の部品表面に付着するメカニズムについて検討寸るとともに，火山灰が堆積した基 材を対象に高温暴露試験を実施した. その結果, 高速で衝突した火山灰によって基材表面は大きく変形していたことから, 火山灰は力学的結合のもと基材に強固に付着していることが推則された. 高温暴露試験より, 火山灰堆積により基材表面で は高温腐食が進行していくことがわかった. 特に, 静的に火山灰を堆積させた試験片に比べて高速衝突することで火山灰が 堆積した試験片において，より腐食が内部一進行することもわかった.

\section{文献}

Chen, W.R. and Zhao, L.R., Review-Volcanic ash and its influence on aircraft engine components, Procedia Engineering, Vol.99 (2015), pp.795-803.

Crown, J.C., Supersonic nozzle design, Technical note-National Advisory Committee for Aeronautics, No.1651 (1948).

片野田洋, CS における粒子の流れ，日本溶射学会誌, Vol.47, No.4 (2010), pp.172-178.

Krämer, S., Faulhaber, S., Chambers, M., Clarke, D.R., Levi, C.G., Hutchinson, J.W. and Evans, A.G., Mechanisms of cracking and delamination within thick thermal barrier systems in aero-engines subject to calcium-magnesium-alumino-silicate (CMAS) penetration, Materials Science and Engineering, Vol.490 (2008), pp.26-35.

富士山ハザードマップ検討委員会，富士山ハザードマップ検討委員会報告書，内閣府 (2004), < http://www.bousai.go.jp/kazan/fujisan-kyougikai/report/>,(参照日 2016 年 3 月 18 日)

$\mathrm{Su}, \mathrm{L}$., Chen, X. and Wang, T.J., Numerical analysis of CMAS penetration induced interfacial delamination of transversely isotropic ceramic coat in thermal barrier coating system, Surface and Coatings Technology, Vol.280, No.28 (2015), pp.100-109.

\section{References}

Chen, W.R. and Zhao, L.R., Review-Volcanic ash and its influence on aircraft engine components, Procedia Engineering, Vol.99 (2015), pp.795-803.

Crown, J.C., Supersonic nozzle design, Technical note-National Advisory Committee for Aeronautics, No.1651 (1948).

Katanoda, H., Particle flow in cold spray process, Journal of the Japan Thermal Spray Society, Vol.47, No.4 (2010), pp.172178 (in Japanese).

Krämer, S., Faulhaber, S., Chambers, M., Clarke, D.R., Levi, C.G., Hutchinson, J.W. and Evans, A.G., Mechanisms of cracking and delamination within thick thermal barrier systems in aero-engines subject to calcium-magnesium-alumino-silicate (CMAS) penetration, Materials Science and Engineering, Vol.490 (2008), pp.26-35.

Review Committee of Volcanic Hazard Mitigation, Report of the review committee of volcanic hazard mitigation (Fujisan hazard map kento iinkai hokokusho), Cabinet Office (2004), available from <http://www.bousai.go.jp/kazan/fujisankyougikai/report/>, (accessed on 18 March, 2016) (in Japanese).

$\mathrm{Su}, \mathrm{L}$., Chen, X. and Wang, T.J., Numerical analysis of CMAS penetration induced interfacial delamination of transversely isotropic ceramic coat in thermal barrier coating system, Surface and Coatings Technology, Vol.280, No.28 (2015), pp.100-109. 